\title{
Colorectal Signet Ring Cell Carcinoma
}

National Cancer Institute

\section{Source}

National Cancer Institute. Colorectal Signet Ring Cell Carcinoma. NCI Thesaurus. Code C43586.

An invasive colorectal adenocarcinoma characterized by the presence of malignant glandular epithelial cells with prominent intracytoplasmic mucin resulting in the displacement of the nuclei. The malignant glandular cells with intracytoplasmic mucin constitute more than $50 \%$ of the malignant cellular infiltrate. 